\title{
The final frontier
}

\author{
By Jon Eldredge* \\ Chief, Collection \& Information Resources Development \\ Medical Center Library, University of New Mexico
}

\section{Pioneers in academic library promotion win ALA's John Cotton Dana Library Public Relations Awards.}

$\mathbf{T}$ wo academic libraries on the cutting edge of library promotion have won Special Awards in the 1987 John Cotton Dana Library Public Relations Award contest. This contest, now in its 42 nd year, is the oldest existing U.S. competition that honors excellence in library management. ALA and the H.W. Wilson Company have continuously cosponsored this annual contest since 1946 to commemorate the career of library PR pioneer John Cotton Dana.

North Texas State University and Northern Illinois University both won Special Awards this year. Both entries were based upon unified graphic design themes. A total of 132 libraries and information centers competed in the contest. After a week of deliberations in New York during March, the judges selected 18 winners. Of the nine academic library contestants, two emerged as winners. These two winners had dared to venture where few academic libraries had dared ever to go before.

\section{Old movies at NTSU}

North Texas State University won a Special Award for its "Tough Guys Fight Crime" PR campaign. This program generated user awareness about the high costs resulting from the theft and mutilation of library collections. The centerpiece

*The author is outgoing chair of the ALA John Cotton Dana Library Public Relations Award Contest Judging Committee. of the campaign was a graphics design series that humorously depicted stars from classic old movies. The graphics were used for both posters and bookmarks. The graphics component was reinforced outside the library through displays, talks to campus groups, newspaper editorials and other media. The PR campaign was implemented during the 1985-1986 academic year.

The campaign was managed by the library's Committee on Theft and Mutilation of Library Materials. The Director originally appointed the Committee to study the extent of these problems, calculate the costs to the library, and propose solutions to the administration. Committee Chair Connie Dowell's initial reaction to the assignment was extreme disappointment, since issues of mutilation and theft seemed fundamentally boring. Dowell's colleagues on the Committee, consisting of several librarians and library assistants (mostly library school students), shared her preliminary indifference to the project. ${ }^{1}$ Nevertheless, the Committee began work on the project in what Dowell described as a "typical librarian way-we compiled a bibliography." The Committee then interviewed Interlibrary loan and collection development librarians to ascertain the costs related to replacing library materials. This step inadvertently provided

${ }^{1}$ Other members of the Committee were Kenneth Lavender, Jean Crabille, Twyla Thompson, Bob Follett, Lyn Townsel, Jan Byron, and Melody Kelly. 
a foundation of staff support for the Committee's campaign that followed. The Committee learned about the kinds of damage subjected to materials and identified the apparent user attitudes that typically led to this destructive behavior.

Dowell's previous career in PR and journalism enabled her to recognize the challenging library promotional opportunity presented by the Committee's research results. The Committee proposed and the library administration approved a change in program focus toward heightening user awareness of the problem. At this point the Committee began to experience excitement about the project. The Committee elected to utilize an attentiongetting, humorous approach to achieving its goals rather than relying on a stern, disciplinarian role for the NTSU librarians.

A staff member from the NTSU Public Affairs Information Service, who was pursuing an advanced degree in art, created the artwork for the graphic designs. The artist was able to earn course credit toward this degree through his involvement in the project. Every detail of these graphic designs was carefully planned by the Committee. The campus printing press reproduced these designs on both bookmarks and posters. Table 1 outlines the costs incurred. The three classic movie design themes were selected for the universality of their appeal.

The posters appeared throughout the campus and served as backdrops for display cases that revolved around individual design themes. For example, the James Cagney poster appeared in a gangster theme display that featured a violin case containing an antique gun, bullets, cigars, and paper money. The John Wayne display featured an antique lariat, spurs, branding irons, and saddlebags provided by an on-campus historical museum.

Two different incidents involving display cases in the library provided an unusual indication of the program's success in educating users about material mutilation. On these occasions librarians were purposely shredding personal copies of magazines for these displays. Users passing by what appeared to be mutilators caught in the act promptly reported the incidents to nearby service desks.

As part of the PR campaign, library instruction librarians were asked to give talks to groups on campus. These talks centered on the losses inflicted

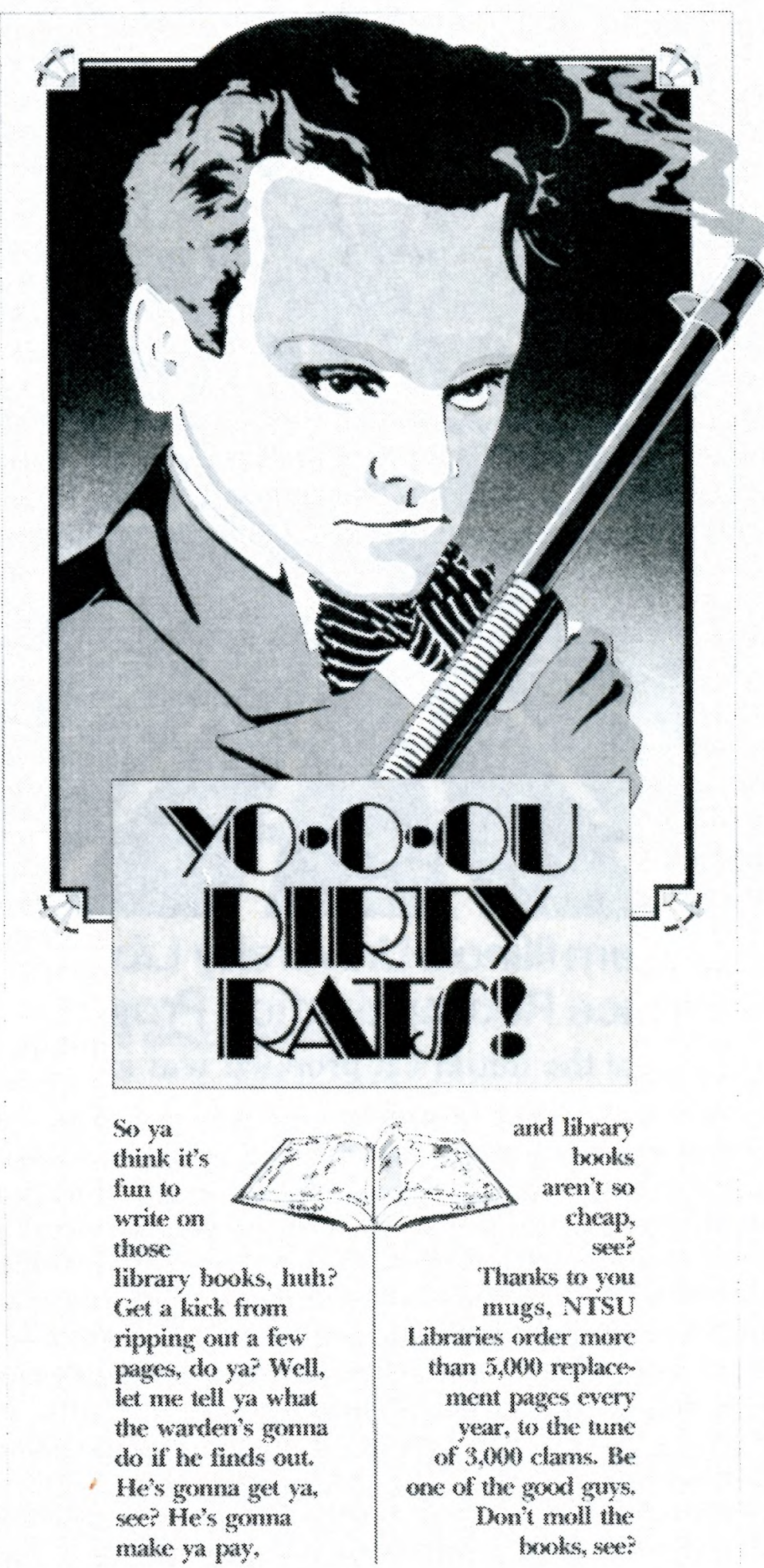

North Texas State University's award-winning poster series features James Cagney.

upon all library users when isolated individuals mutilated or stole materials from the collections. The posters were brought to these talks and the corresponding bookmarks distributed to the audiences.

The library administration gave the Committee a fair amount of autonomy to develop this cam-

TABLE 1

\section{NTSU GRAPHICS COSTS}

\begin{tabular}{lccc}
\hline \hline \multicolumn{1}{c}{ Item } & Quantity & Total Cost & Per Unit Cost \\
Posters & 1,000 & $\$ 700$ & $\$ 0.70$ \\
Bookmarks & 6,900 & $\$ 985$ & $\$ 0.14$
\end{tabular}

The materials cost of $\$ 1,685$ represented $.04 \%$ of the total annual NTSU Library budget of $\$ 4,066,878$. 


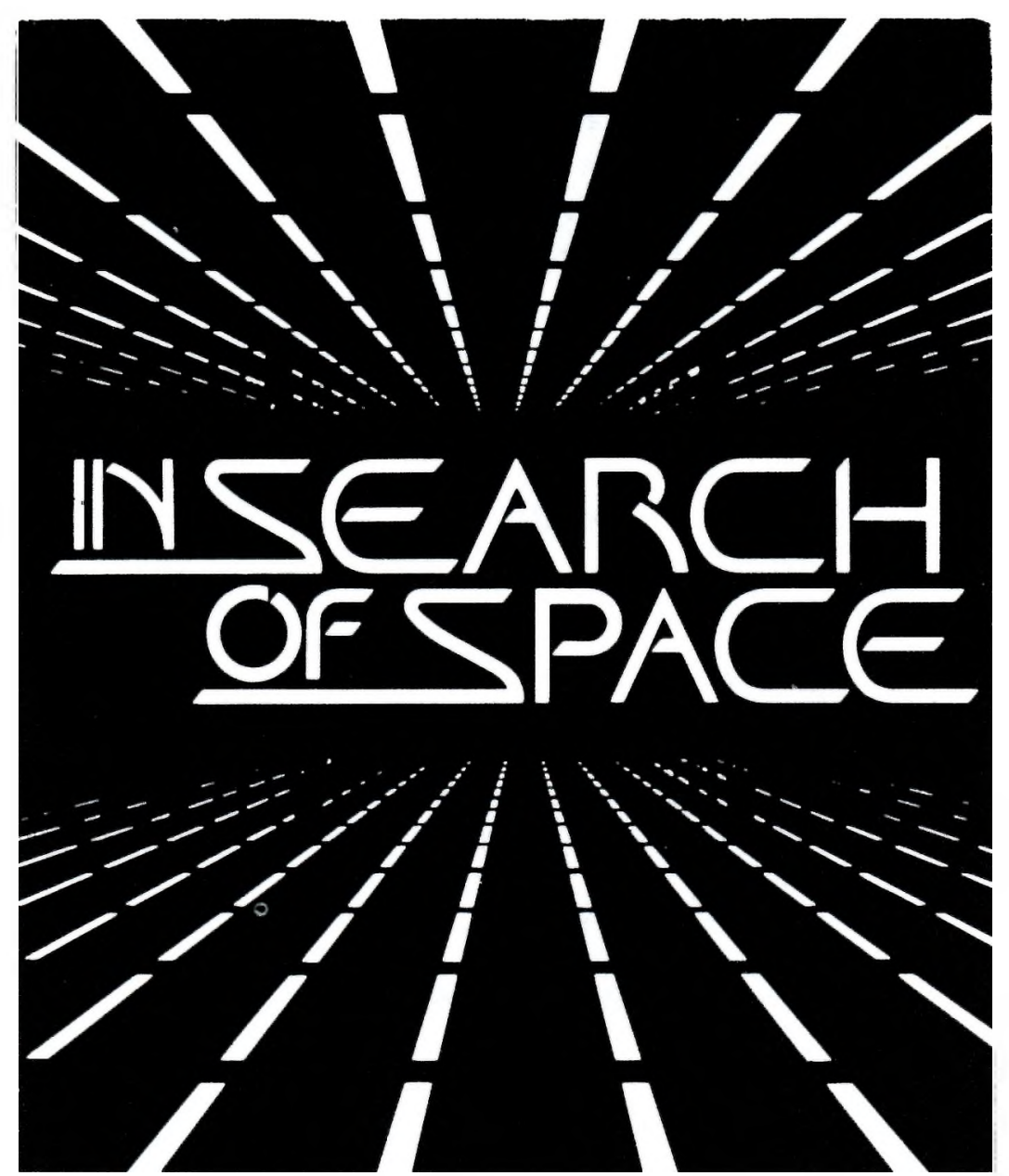

Northern Illinois University Libraries Space Reorganization Project

paign once the initial PR proposal was approved. Dowell was thrilled to observe the wide participation in the campaign that extended beyond the library to other departments on campus. "This genuine, sustained group effort turned out to be the most gratifying aspect of the campaign," she reported. Dowell found that her Committee needed to possess neither the materials nor skills required to complete the project. These resourceful librarians instead sought assistance from the museum, Public Affairs Information Service, and printing press at NTSU. Dowell attributed project success to this effective utilization of available resources, plus the development of a solid theme around which the Committee could build a campaign.

What had begun as a seemingly dull assignment ended last year as one of the most fun projects ever pursued by any of the individual committee members. Dowell stated that the campaign was intrinsically rewarding since it "involved meeting a local need with locally produced materials." Dowell also added that because they had so much fun with the campaign, "entering the contest was an afterthought." $"$

Edward Johnson, director of the NTSU Libraries, views PR as an essential element in library management. For this reason, Johnson expresses surprise that more academic libraries do not think PR has an important role. "Academic libraries," he notes, "have so many opportunities which they seem to constantly pass up." For example, few academic libraries celebrate National Library Week.

${ }^{2}$ Additional information about the Committee can be found in Connie Dowell's article in the Summer 1986 issue of Texas Library Journal, pp.138-39.
During the past few years though, NTSU has sponsored major programs in observance of NLW. Recently Johnson was contacted by the ALA Public Information Office about turning over the graphic designs used by NTSU in its campaign against theft and mutilation for wide distribution by ALA. If this transfer can be effected, academic libraries will be able to purchase these wonderful graphic designs for their own PR programs.

\section{In search of space}

Northern Illinois University won a Special Award for its well-managed, creative PR campaign designed to overcome disruptions associated with a major renovation project. This thoroughly planned PR campaign succeeded in meeting its dual goals of preserving healthy relations with users and maintaining normal usage of the collections. Approximately 7,600 people entered this library on a typical weekday when classes were in session.

The clever graphic design and slogan combination "In Search of Space" served as the unifying device for the entire NIU renovation project. This PR theme was loosely based upon a poster for the Star Trek movie entitled "In Search of Spock." Gordon Rowley, associate director for research services at NIU, described the theme's ability to unify many disparate elements as the most innovative feature of the PR campaign. This graphic design appeared on T-shirts, bookmarks, banners, stationery, buttons, and in newspaper articles. Graphic artist Carlos J. Granados created the visual design while the staff selected the slogan, "In Search of Space." Granados chose the visual design to represent abstractly the rows of fluorescent lights and striped patterns on the carpet planned for the renovated library. The PR campaign also incorporated strategies to utilize press communications as well as personal contacts to achieve its goals.

The library renovation project was managed by the Planning and Implementation Team composed of librarians and staff members. The Team recognized at the outset the need for a vigorous PR component to the renovation plan to avoid an erosion of the library's good reputation. Although the Team appointed an information officer to coordinate most promotional activities, other Team members played pivotal roles in managing the PR campaign. The Team realized in the early planning phase that the cooperation of library staff would be a crucial ingredient in the success of the overall project. Members accurately predicted that the staff would be subjected to stressful working conditions. The Team consequently strove to build staff support and morale by offering stress workshops, contests, and service commendations throughout the renovation period. The Team also made efforts to keep staff members informed about all significant developments connected with the renovation. The NIU entry received high marks from the judges for its 
treatment of an important, but frequently overlooked aspect of a PR campaign-staff relations.

The NIU library's Planning and Implementation Team employed appropriate evaluation methods to measure the success of the PR campaign. Contest judges were impressed by the fact the NIU entry included statistics for a three-year period which strengthened the reliability of evaluation claims. The entry scrapbook provided evidence that the six measurable program objectives were met by the "In Search of Space" campaign. Relations with the faculty and student target groups remained healthy, as indicated by the fact that only $2.4 \%$ of the comments submitted to the library suggestion box even mentioned the renovation. The campus newspaper received no negative letters to the editor about the renovation; nor did it publish any articles or editorials critical of the renovation. Nearly normal levels of collection usage were recorded in spite of the obvious obstacles to access encountered by users. Circulation decreased by only $8.4 \%$ while in-house usage dropped only $3.1 \%$ during the transitional phase. Reference inquiries actually increased by $67.9 \%$, a surprising jump.

Several favorable outcomes have resulted from successful completion of the PR campaign. The administration plans to apply the team concept to future projects due to the many beneficial effects not only on employee morale but on faculty, students and administrators. Theodore F. Welch, director of libraries, pointed out that "the information dissemination network created through the project's public relations component fostered an evironment in which library users were receptive to highly visible change in the library. And perhaps, even more significantly, the results enabled the libraries and the university to initiate planning efforts for approaching the next inevitable frontier: the expansion of library facilities beyond the existing level."

\section{The final round}

The two winning entries will be on display in the exhibits area at the ALA Annual Conference in San Francisco. Readers interested in learning about the history of academic library involvement in the contest should refer to the author's annual articles since 1983 in C $b R L$ News. These articles also offer advice on how academic libraries might effectively compete in the contest. This was the fourth and final year for the author's service as a contest judge. He was pleasantly surprised to observe the high quality of the entries from academic libraries this year.

Four entries from academic libraries reached the final round of judging. All entries during the final round are subjected to rigorous scrutiny in a process that involves comparing all entries to one another. This means that the best public, school, and special library entries compete against the best academic library entries at this stage. The two nonwinning academic libraries lost by narrow margins in the final round, which indicates an ability of academic libraries to compete strongly against other types of libraries. Descriptions of these two nonwinning entries, plus another academic library entry eliminated in an earlier round, will appear in the fourth edition of Great Library Promotion Ideas (1988). This ALA publication describes the winning entries and notable non-winning entries from each annual contest. ${ }^{3}$ Entry packets for next year's contest are available from the Marketing Department at the H.W. Wilson Company, 950 University Avenue, Bronx, NY 10452. This judge hopes his articles will encourage academic libraries to compete successfully in future contests.

${ }^{3}$ Contact John Berry, executive director, ALA/ LAMA, for details.

\section{Letter}

\section{Reference desk staffing}

\section{To the Editor:}

This is in response to the article, "Staffing the reference desk during conferences," by Tara Lynn Fulton, published in the March 1987 C \& RL News.

One viable way to cope with professional staff shortages is to employ qualified temporary reference librarians during such critical-need periods. While most of your readers may tend to think of hiring "temporary" professionals and paraprofessionals for longer periods of time than a few days, I wish to point out that a service like C. Berger and Company is able to supply competent temporary staff for such short periods. (For an excellent article on aspects of longer-term temporary employment, readers may want to refer to "T is for Temporary," by Donna Zufan Pontau and M. Cecelia Rothschild, in College \& Research Libraries, March 1986.) In fact, there is no need to compromise either service to the patron or professional staff development, as use of temporaries can be a costeffective way to assure proper $\operatorname{staffin}_{\dot{\varepsilon}}^{r}$ when such a conflict occurs.

One problem I have observed which may prevent librarians from using temporary staff is a budgeting one. Note that I did not say "budgetary," since this term implies that adequate funds do not exist, whereas often they do. However, until a line is incorporated into the library's budget which would allow for engaging temporaries, actual employment of them may not be easy. Sometimes, dollars available due to ordinary staff attrition can be used, but I submit that planning for temporary staff by incorporating a modest sum in the annual budget is a better method.-Carol A. Berger, $C$. Berger \& Co., Wheaton, Illinois. 


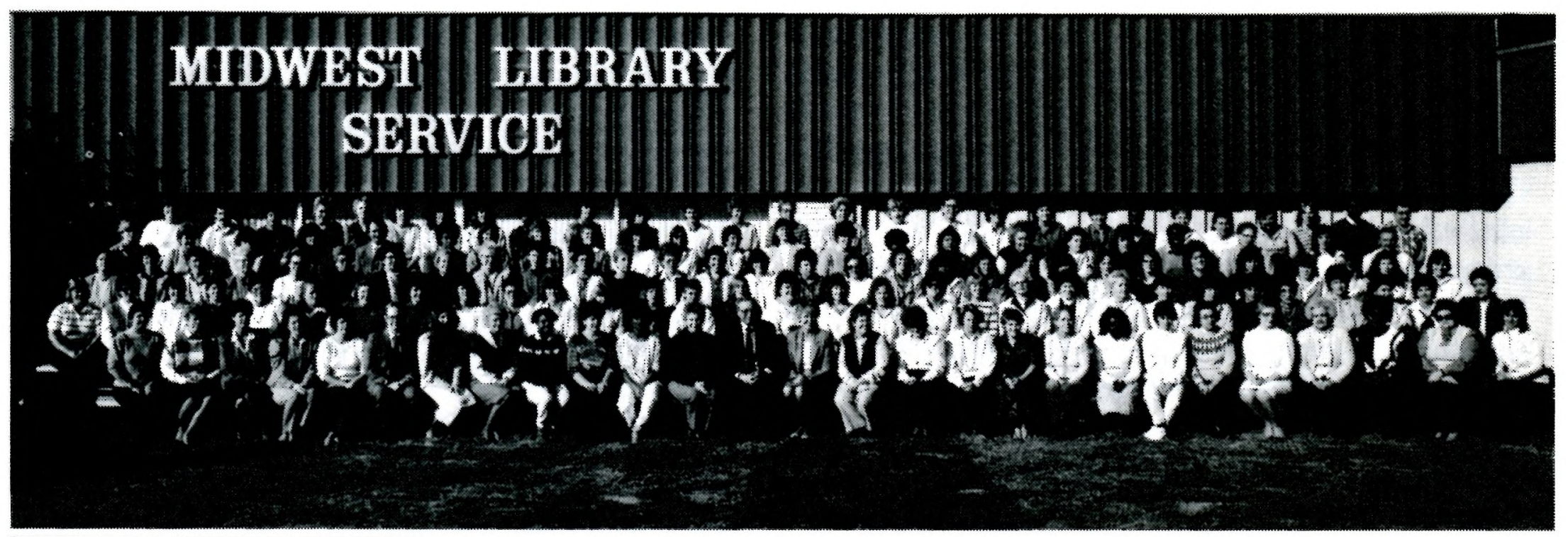

\section{When You Call MLS, The Whole Team Answers!}

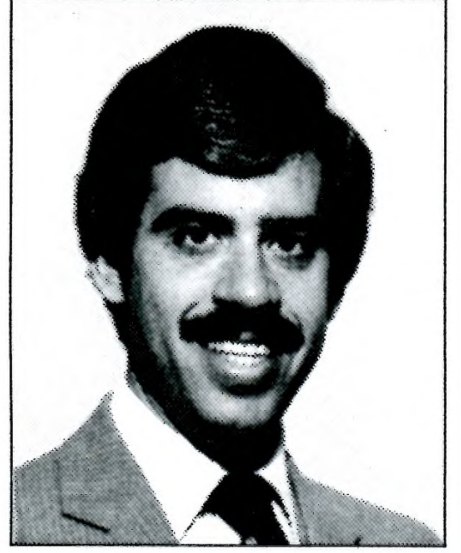

Jay Askuvich General Sales Manager

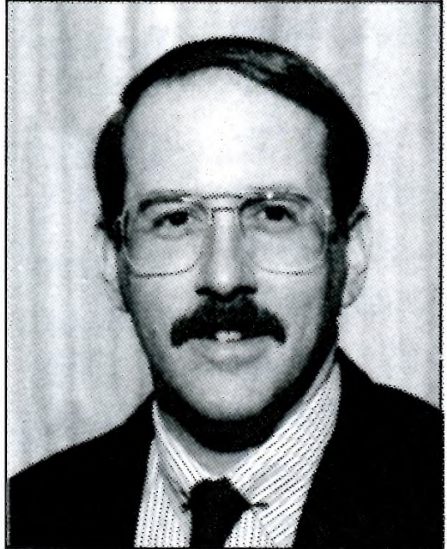

Scott Schmidt Midwest

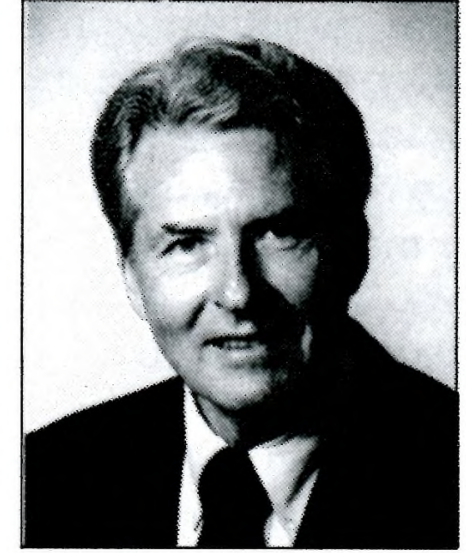

Carl Dorr

Southeast

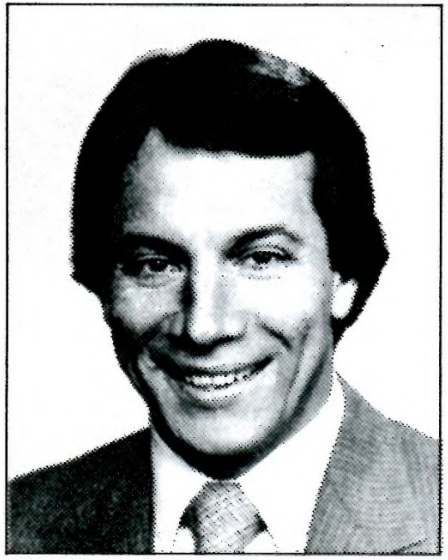

Lawrence Nagel West

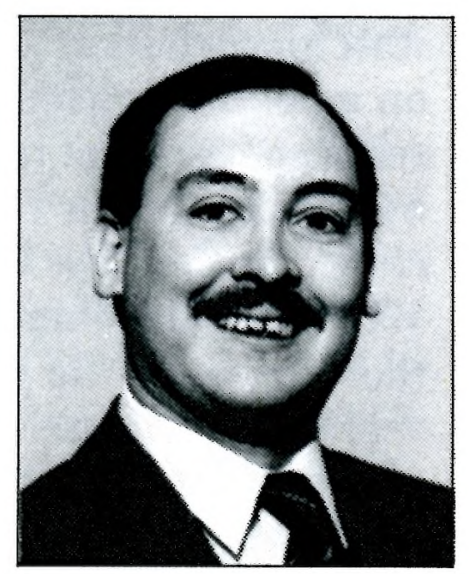

Forrest Link

Northeast

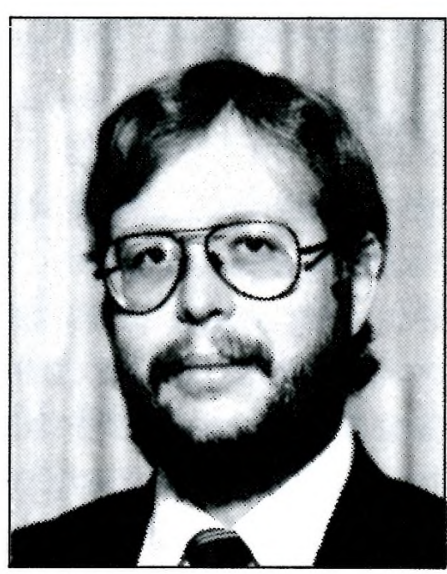

Kim Anderson Mountain Plains

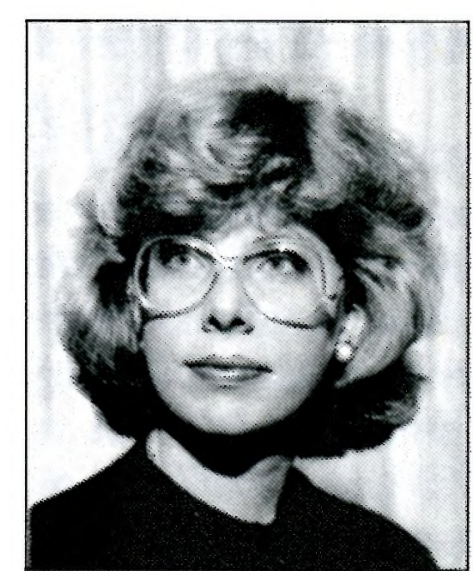

Lorraine Best

Canada

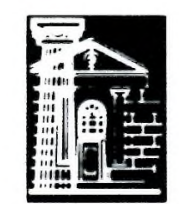

Midwest Library Service

11443 St. Charles Rock Road Bridgeton, MO 63044, USA

Call toll-free 1-800-325-8833 Missouri librarians call toll-free 1-800-392-5024 Canadian librarians call toll-free 1-800-527-1659 